\title{
Characterization of Vascular Endothelial Growth Factor's Effect on the Activation of Protein Kinase C, Its Isoforms, and Endothelial Cell Growth
}

\author{
Pu Xia, Lloyd Paul Aiello, ${ }^{\star}$ Hidehiro Ishii, Zhen Y. Jiang, Do Joon Park, Gregory S. Robinson, ${ }^{\ddagger}$ Hitoshi Takagi, \\ William P. Newsome, Michael R. Jirousek, $\$$ and George L. King \\ Research Division and *Beetham Eye Institute, Joslin Diabetes Center, Department of Medicine, Brigham and Women's Hospital and \\ Harvard Medical School, Boston, Massachusetts 02215; ${ }^{\ddagger}$ Hybridon Inc., Worcester, Massachusetts; and ${ }^{\S}$ Lilly Laboratories, Indianapolis, \\ Indiana 46285
}

\begin{abstract}
Vascular endothelial growth factor (VEGF) is a potent endothelial cell mitogen which mediates its effects by binding to tyrosine kinase receptors. We have characterized the VEGF-activated intracellular signal transduction pathway in bovine aortic endothelial cells and correlated this to its mitogenic effects. VEGF induced concentration- and timedependent increases in protein kinase $\mathrm{C}$ (PKC) activation with a maximum of 2.2 -fold above the basal level at $5 \times$ $10^{-10} \mathrm{M}$ within $10 \mathrm{~min}$ as measured both by in situ and translocation assays. Immunoblotting analysis of PKC isoforms in cytosolic and membrane fractions indicated that after VEGF stimulation the content of $\mathrm{Ca}^{2+}$-sensitive PKC isoforms ( $\alpha$ and $\beta I I)$ was increased in the membrane fractions, whereas no changes were observed for PKC isoforms $\delta$ and $\epsilon$. The stimulation of PKC activity by VEGF was preceded by the activation of phospholipase $\mathrm{C} \gamma$ (PLC $\gamma)$. This was demonstrated by parallel increases in PLC $\gamma$ tyrosine phosphorylation, $\left[{ }^{3} \mathrm{H}\right]$ inositol phosphate production, and $\left[{ }^{3} \mathrm{H}\right]$ arachidonic acid-labeled diacylglycerol formation in bovine aortic endothelial cells. In addition, VEGF increased phosphatidylinositol 3-kinase activity 2.1-fold which was inhibited by wortmannin, a phosphatidylinositol 3-kinase inhibitor, without decreasing the VEGF-induced increase in PKC activity or endothelial cell growth. Interestingly, genistein, a tyrosine kinase inhibitor, and GFX or $\mathrm{H}-7$, PKC inhibitors, abolished both VEGF-induced PKC activation and endothelial cell proliferation. VEGF's mitogenic effect was inhibited by a PKC isoform $\beta$-selective inhibitor, LY333531, in a concentration-dependent manner. In contrast, antisense PKC- $\alpha$ oligonucleotides enhanced VEGF-stimulated cell growth with a simultaneous decrease of $70 \%$ in PKC- $\alpha$ protein content. Thus, VEGF appears to mediate its mitogenic effects partly through the activation of the PLC $\gamma$ and PKC pathway, involving predominately PKC- $\beta$ isoform activation in endothelial cells. (J. Clin. Invest. 1996. 98:2018-2026.) Key words: vascular endothelial growth fac-
\end{abstract}

Address correspondence to George L. King, M.D., Joslin Diabetes Center, One Joslin Place, Boston, MA 02215. Phone: 617-732-2622; FAX: 617-732-2637.

Received for publication 31 October 1995 and accepted in revised form 17 September 1996.

J. Clin. Invest.

(c) The American Society for Clinical Investigation, Inc. 0021-9738/96/11/2018/09 \$2.00

Volume 98, Number 9, November 1996, 2018-2026 tor - signal transduction - phospholipase $\mathrm{C} \gamma \cdot$ protein kinase $\mathrm{C} \cdot$ proliferation

\section{Introduction}

Vascular endothelial growth factor (VEGF) ${ }^{1}$ a potent endothelial cell mitogen, is postulated to be the major growth factor responsible for hypoxia-stimulated angiogenesis $(1,2)$. VEGF was independently isolated as both an endothelial cell growth factor (1) and as a vasopermeability factor (3). The expression of VEGF is greatly increased by hypoxia both in vivo and in many types of cultured cells including vascular endothelial cells (4-6). Physiologically, elevated levels of VEGF have been associated with tumor angiogenesis (7) and hypoxia-induced proliferative ocular disorders such as diabetic proliferative retinopathy and retinal vein occlusion $(8,9)$.

VEGF exerts its actions by binding to specific plasma membrane receptors which are transmembrane glycoproteins with an extracellular ligand-binding domain and an intracellular tyrosine kinase domain (2). Recent studies have demonstrated two types of high-affinity receptors for VEGF, fms-like tyrosine kinase (flt) and fetal liver kinase-1 (flk-1) $(10,11)$. These receptors share structural similarities to the $\alpha$ - and $\beta$-forms of PDGF receptor $(10,11)$. VEGF has been reported to increase the tyrosine phosphorylation of phospholipase $\mathrm{C} \gamma$ (PLC $\gamma$ ) and phosphatidylinositol 3-kinase (PI 3-kinase), suggesting that these signal transduction pathways could be involved during VEGF activation $(12,13)$. However, it has not been demonstrated whether VEGF can activate these enzymatic systems, and their relationship to endothelial cell proliferation has not been evaluated. In these studies, we have characterized the activation of PI 3-kinase, PLC $\gamma$, and the protein kinase $\mathrm{C}$ (PKC) pathways in vascular endothelial cells responding to VEGF stimulation. The relationship between the activation of various PKC isoforms and VEGF's mitogenic effects has been investigated.

\section{Methods}

Materials. Recombinant human VEGF was kindly provided by Dr. N. Ferrara (Genentech Inc., South San Francisco, CA). Polyclonal antisera to PKC- $\alpha,-\beta I,-\beta I I,-\delta,-\epsilon$, and $-\zeta$ were generated in collaboration with Lilly, Inc. (Indianapolis, IN) and their specificities have been described previously (14). Polyclonal antibody to PKC- $\beta$ was

1. Abbreviations used in this paper: BAEC, bovine aortic endothelial cell; DAG, diacylglycerol; GFX, GF109203X; $\mathrm{IP}_{3}$, inositol triphosphate; PDHS, plasma-derived horse serum; PI 3-kinase, phosphatidylinositol 3-kinase; PKC, protein kinase C; PLC $\gamma$, phospholipase $\mathrm{C} \gamma$; VEGF, vascular endothelial growth factor. 
purchased from Gibco Laboratories (Grand Island, NY). Monoclonal antiserum to phosphotyrosine (4G10) and polyclonal antiserum to PLC $\gamma$ were purchased from Upstate Biotechnology, Inc. (Lake Placid, NY). $\left[\gamma_{-}{ }^{32} \mathrm{P}\right] \mathrm{ATP},\left[{ }^{3} \mathrm{H}\right]$ myoinositol, and $\left[{ }^{3} \mathrm{H}\right]$ arachidonic acid were obtained from Du Pont/New England Nuclear (Boston, MA). [ $\left.{ }^{125} \mathrm{I}\right]$ Protein-A was purchased from Amersham Corp. (Arlington Heights, IL). Genistein, H-7, H-8, and GF109203X (GFX) were purchased from LC Laboratories (Boston, MA). PMA, wortmannin, and other chemical reagents were purchased from Sigma Chemical Co. (St. Louis, MO). PKC- $\beta$ inhibitor, LY333531 [a macrocyclic bis(indolyl)maleimide] was developed in collaboration with Lilly Laboratories and its structure and specificity have been described previously (15).

Cell culture. The isolation and primary culture of bovine aortic endothelial cells (BAEC) have been previously described in detail (16). The cells were cultured in DME supplemented with $10 \%$ plasma-derived horse serum (PDHS) (Lampire, Pipersville, PA). Cultured BAEC from passages 3-10 were used for all experiments.

Measurement of in situ PKC activity. The measurement of PKC activity in situ was performed using the method of Heasley and Johnson (17) with some modifications (18). BAEC were seeded in 24well plates and maintained in culture medium until $70-80 \%$ confluent. After the addition of VEGF or other agents, the cells were washed with DME and placed in $60 \mu \mathrm{l}$ of a buffered salt solution (137 $\mathrm{mM} \mathrm{NaCl}, 5.4 \mathrm{mM} \mathrm{KCl}, 0.3 \mathrm{mM} \mathrm{Na}_{2} \mathrm{HPO}_{4}, 0.4 \mathrm{mM} \mathrm{KH}_{2} \mathrm{PO}_{4}, 5.5 \mathrm{mM}$ glucose, and $20 \mathrm{mM}$ Hepes) supplemented with $50 \mu \mathrm{g} / \mathrm{ml}$ digitonin, 10 $\mathrm{mM} \mathrm{MgCl} 2,25 \mathrm{mM} \beta$-glycerophosphate, and $100 \mu \mathrm{M}\left[\gamma^{3}{ }^{32} \mathrm{P}\right] \mathrm{ATP}$ $(5,000 \mathrm{cpm} / \mathrm{pmol})$. Further additions for the specific assay of PKC were $5 \mathrm{mM}$ EGTA, $2.5 \mathrm{mM} \mathrm{CaCl}_{2}$, and $200 \mu \mathrm{M}$ of PKC-specific peptide substrate (RKRTLRRL). The kinase reaction was terminated after a 10 -min incubation at $30^{\circ} \mathrm{C}$ with $20 \mu \mathrm{l}$ of $25 \%$ (wt/vol) trichloroacetic acid. Aliquots $(65 \mu \mathrm{l})$ of the acidified reaction mixtures were spotted on $2 \times 2 \mathrm{~cm}$ phosphocellulose squares (Whatman P-81) and washed batchwise with three changes of $75 \mathrm{mM}$ phosphoric acid and one change of $75 \mathrm{mM}$ sodium phosphate ( $\mathrm{pH}$ 7.5). The PKC-dependent phosphorylated peptide substrate bound to the filter was quantified by scintillation counting. Protein was dissolved in $0.2 \mathrm{~N} \mathrm{NaOH}$ and assayed by the method of Bradford (19).

Measurement of intracellular distribution of PKC activity and isoforms. After VEGF stimulation, BAEC were harvested and homogenized in ice-cold buffer containing $20 \mathrm{mM}$ Tris/HCl, $\mathrm{pH}$ 7.5, $2 \mathrm{mM}$ EDTA, 0.5 mM EGTA, $1 \mathrm{mM}$ PMSF, and $0.05 \%$ leupeptin, and fractionated into cytosolic and membrane fractions according to the method described previously (16). PKC activity in both fractions was determined by measuring phosphatidylserine/diacylglycerol-dependent phosphorylation of exogenous $\mathrm{PKC}$-specific peptide substrate (RKRTLRRL) in the presence of $\mathrm{Ca}^{2+}$. The kinase reaction was terminated after $5 \mathrm{~min}$ at $30^{\circ} \mathrm{C}$. Specific PKC activity was calculated by subtracting the nonspecific kinase activities from those obtained in the presence of phosphatidylserine/diacylglycerol and $\mathrm{Ca}^{2+}$. For determining the distribution of PKC isoforms in BAEC, aliquots of equivalent amounts of protein extracted from both cytosolic and membrane fractions were analyzed by SDS-PAGE as described previously (20). The immunoblots were probed with monospecific antiPKC isoform peptide antibodies purified by affinity column. The antipeptide polyclonal antibodies were made against peptide specific for PKC- $\alpha,-\beta I,-\beta I I,-\delta,-\epsilon$, and $-\zeta$. A detailed description of these antibodies has been reported previously $(14,21)$. The enhanced chemiluminescent detection system (ECL; Amersham Corp.) was used for the immunoblot protein detection.

Immunoprecipitation of PLC $\gamma$. After treatment with or without VEGF, BAEC were lysed in ice-cold buffer containing $20 \mathrm{mM}$ Tris/ $\mathrm{HCl}, \mathrm{pH} 7.6,0.1 \%$ SDS, $1 \%$ Triton $\mathrm{X}-100,0.5 \%$ deoxycholate, 150 $\mathrm{mM} \mathrm{NaCl}, 1 \mathrm{mM}$ PMSF, $2 \mu \mathrm{g} / \mathrm{ml}$ aprotinin, $10 \mu \mathrm{g} / \mathrm{ml}$ leupeptin, $5 \mu \mathrm{g} /$ $\mathrm{ml}$ pepstatin, $1 \mathrm{mM} \mathrm{NaF}$, and $0.5 \mathrm{mM} \mathrm{Na} \mathrm{VO}_{4}$. Solubilized cells were centrifuged at $15,000 \mathrm{~g}$ for $10 \mathrm{~min}$ at $4^{\circ} \mathrm{C}$, and the supernatants (equivalent amounts of protein content) were immunoprecipitated by incubation with anti-PLC $\gamma$ polyclonal antisera bound to protein A-Sepharose beads (Pharmacia Biotech Inc., Piscataway, NJ) at $4^{\circ} \mathrm{C}$ overnight.
After washing three times with lysis buffer, the immunoprecipitates were dissolved in Laemmli's sample buffer, separated by $4-12 \%$ SDSPAGE, transferred to nitrocellulose membranes, and probed successively with polyclonal antiphosphotyrosine antibodies. Tyrosinephosphorylated PLC $\gamma$ was detected and quantitated by PhosphorImager analysis.

Measurement of diacylglycerol $(D A G)$. BAEC were seeded in 6-well plates and grown to $70-80 \%$ confluent. Cells were labeled with $5 \mu \mathrm{Ci} / \mathrm{ml}$ of $\left[{ }^{3} \mathrm{H}\right]$ arachidonic acid and incubated for $16 \mathrm{~h}$, and the label was removed by washing cells three times with DME. After an equilibration period of $20 \mathrm{~min}$ in DME containing $0.1 \% \mathrm{BSA}$, cells were stimulated with VEGF. The reaction was terminated by aspiration of medium and the addition of $1 \mathrm{ml}$ ice-cold methanol. The cells were scraped and total lipids were extracted with chloroform according to the methods of Bligh and Dyer (22). [ $\left.{ }^{3} \mathrm{H}\right] \mathrm{DAG}$ was separated by silica gel G TLC and quantified by liquid scintillation counter as described previously (16). $\left[{ }^{3} \mathrm{H}\right] \mathrm{DAG}$ was normalized by the radioactivity recovered in $\mathrm{CHCl}_{3}$ extracts of total cellular lipids.

Measurement of inositol phospholipids formation. BAEC were seeded in 6-well plates and maintained in regular culture medium. When the cells were $70-80 \%$ confluent, medium was changed to DME containing $2 \%$ PDHS with $1 \mu \mathrm{Ci} / \mathrm{ml}$ of $\left[{ }^{3} \mathrm{H}\right]$ myo-inositol. After 16-20 h of labeling, the cells were rinsed twice with DME containing $20 \mathrm{mM}$ Hepes ( $\mathrm{pH} 7.3$ ), $20 \mathrm{mM} \mathrm{LiCl}$, and $0.1 \% \mathrm{BSA}$, and incubated in the same solution at $37^{\circ} \mathrm{C}$ for $20 \mathrm{~min}$. Cells were stimulated with various concentrations of VEGF for $10 \mathrm{~min}$ at $37^{\circ} \mathrm{C}$. The reaction was terminated by rapid aspiration of medium, and the cells were rinsed twice with ice-cold PBS and treated with $0.6 \mathrm{ml}$ of ice-cold $5 \%$ perchloric acid for $30 \mathrm{~min}$. Cells were then scraped and pelleted by centrifugation. The supernatants were diluted 1:15 with water and applied to an AG1-X8 ion exchange column (Bio-Rad, Hercules, CA) for separation of total inositol phosphates from inositols as described previously (23). The production of inositol phospholipids was quantified by scintillation counting.

Separation and activity of PI 3-kinase. After VEGF stimulation, BAEC were lysed in ice-cold lysis buffer containing $50 \mathrm{mM}$ Hepes,

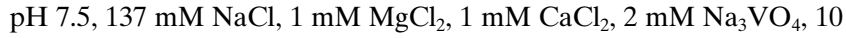
$\mathrm{mM} \mathrm{NaF}, 2 \mathrm{mM}$ EDTA, $1 \%$ Nonidet P-40, $10 \%$ glycerol, $1 \mathrm{mM}$ PMSF, $2 \mu \mathrm{g} / \mathrm{ml}$ aprotinin, $5 \mu \mathrm{g} / \mathrm{ml}$ leupeptin, and $1 \mu \mathrm{g} / \mathrm{ml}$ pepstatin. Insoluble material was removed by centrifugation at $15,000 \mathrm{~g}$ for 10 min at $4^{\circ} \mathrm{C}$. PI 3-kinase was immunoprecipitated from aliquots of the supernatant with antiphosphotyrosine antibodies as described previously (24). After successive washings, the pellets were resuspended in $50 \mu \mathrm{l}$ of $10 \mathrm{mM}$ Tris ( $\mathrm{pH} 7.5), 100 \mathrm{mM} \mathrm{NaCl}$, and $1 \mathrm{mM}$ EDTA. To each pellet was added $10 \mu \mathrm{l}$ of $100 \mathrm{mM} \mathrm{MgCl}_{2}$ and $10 \mu \mathrm{l}$ of phosphatidylinositol $(2 \mu \mathrm{g} / \mu \mathrm{l})$ sonicated in $10 \mathrm{mM}$ Tris $(\mathrm{pH} 7.5)$ with $1 \mathrm{mM}$ EGTA. The PI 3-kinase reaction was initiated by the addition of $5 \mu \mathrm{l}$ of $0.5 \mathrm{mM}$ ATP containing $30 \mu \mathrm{Ci}$ of $\left[\gamma^{-32} \mathrm{P}\right] \mathrm{ATP}$. After $10 \mathrm{~min}$ at room temperature with constant shaking, the reaction was stopped by the addition of $20 \mu \mathrm{l}$ of $8 \mathrm{~N} \mathrm{HCl}$ and $160 \mu \mathrm{l}$ of chloroform/methanol (1:1). The samples were centrifuged, and the organic phase was removed and applied to silica gel TLC plates developing in $\mathrm{CHCl}_{3}$ : $\mathrm{CH}_{3} \mathrm{OH}: \mathrm{H}_{2} \mathrm{O}: \mathrm{NH}_{4} \mathrm{OH}$ (60:47:11:2). The radioactivity in spots which comigrated with a PI-4 standard was measured by Cerenkov counting.

Antisense oligonucleotide synthesis and use. Phosphorothioate oligodeoxynucleotides (oligonucleotides) corresponding to bovine PKC- $\alpha$ were synthesized by Joslin Diabetes Center's Molecular Biology Core (Boston, MA). Sequences of antisense PKC- $\alpha$ nucleotides were $5^{\prime}$-GTCCCTCGCCGCCTCCTG-3', and sense PKC- $\alpha$ nucleotides were $5^{\prime}$-GTCCTCCGCCGCTCCCTG-3'. BAEC were cultured in 6-well plates with DME containing 10\% PDHS. After $24 \mathrm{~h}$, the medium was changed to serum-free DME containing $10 \mu \mathrm{g} / \mathrm{ml}$ DOTMA/ DOPE solution (Lipofectin ${ }^{\circledR}$; Gibco Laboratories). Oligonucleotides were then added at the required concentration and well-mixed with media by swirling of the plate. The cells were incubated at $37^{\circ} \mathrm{C}$ for $6 \mathrm{~h}$, washed once with DME to remove Lipofectin ${ }^{\circledR}$, and then the cells were incubated with DME containing 10\% PDHS and the same con- 
centration of oligonucleotides to maintain exposure in the presence or absence of VEGF for $3 \mathrm{~d}$. Cell growth was measured by assay of DNA content as described below.

$B A E C$ growth assay. BAEC were seeded in 12-well plates at a density of 5,000 cells/well and cultivated in DME containing $10 \%$ of PDHS. After $24 \mathrm{~h}$, the medium was changed and VEGF or other agents were added. At the desired times, the cellular DNA content was measured using Hoechst-33258 dye and a fluorometer (model TKO-100; Hoefer Scientific Instruments, San Francisco, CA) as described previously (8, and see reference 32$)$.

Statistical analysis. Unpaired Student's $t$ test was used for comparison of two groups with normal distributions. ANOVA and the Newman-Keul's tests were used to identify statistical significance of multiple comparisons.
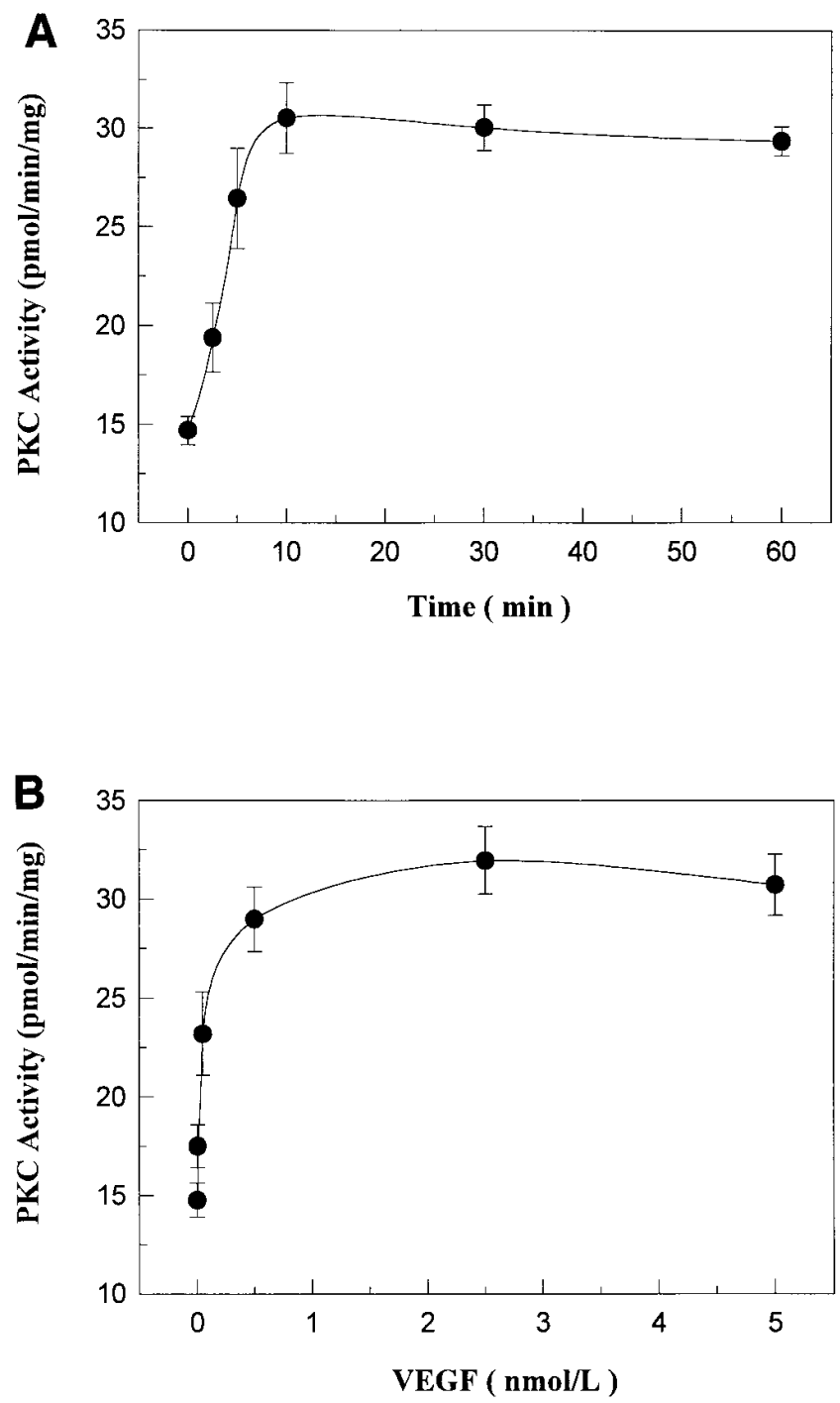

Figure 1. VEGF effect on PKC activation. $(A)$ Time course of VEGF-stimulated PKC activation. After treatment with $0.5 \mathrm{nmol} / \mathrm{li}-$ ter VEGF, cultured BAEC were permeabilized with digitonin and then PKC activity was measured in situ as described in Methods. (B) Dose-response of VEGF-stimulated PKC activation. BAEC were treated with increasing amounts of VEGF for $10 \mathrm{~min}$, and then PKC activity was measured in situ. PKC activity in situ was expressed as PKC-dependent peptide phosphorylation, $\mathrm{pmol} / \mathrm{min} / \mathrm{mg}$ protein. The results are shown as mean \pm SEM from three independent experiments, each performed in triplicate.

\section{Results}

Characterization of VEGF-induced PKC activation. The effect of VEGF on the stimulation of PKC activity was studied first by an in situ assay using digitonin-permeabilized BAEC where phosphorylation levels of a highly specific peptide substrate for PKC (PKRTLRRL) were quantitated (25). VEGF induced increased PKC activation in a time-dependent manner which was detectable within 1 min after the addition of VEGF (Fig. 1 $A$ ). Maximal PKC activation achieved was 2.2-fold greater than basal levels within $10 \mathrm{~min}$ and this activation was sustained for at least $60 \mathrm{~min}$.

VEGF also induced PKC activation in a concentrationdependent manner (Fig. 1 B). A significant increase in PKC activity was detectable at $5 \mathrm{pmol} /$ liter of VEGF, and half-maximal stimulation occurred at 50-100 pmol/liter. The maximal effect of VEGF on PKC activation was observed at $0.5 \mathrm{nmol} /$ liter.

The effect of VEGF on the translocation of PKC from cytosolic to membrane fractions was studied as another indicator of PKC activation. The addition of $0.5 \mathrm{nmol} /$ liter VEGF for 10 min increased the specific activity of PKC in the membrane fraction by twofold with a corresponding $42 \%$ decrease in the cytosolic fraction as shown in Fig. 2.

Since PKC consists of a large family of proteins with multiple isoforms, we characterized the effect of VEGF on the translocation of the various PKC isoforms in BAEC (25). Six PKC isoforms $\left(\alpha, \beta_{1}, \beta_{2}, \delta, \epsilon\right.$, and $\left.\zeta\right)$ were identified by immunoblotting with polyclonal antibodies raised against isoformspecific peptides as reported previously $(14,21)$. As illustrated in Fig. 3, $A$ and $B$, both PKC- $\alpha$ and $-\beta_{2}$ isoforms were found to translocate with a three- to sixfold elevation in the membrane fraction as quantitated by phosphoimaging analysis (Fig. $3 \mathrm{~B}$ ). Decrease in the cytosolic fraction was observed with PKC- $\alpha$ isoform but not with the PKC- $\beta_{2}$ isoform. No significant changes in protein content of PKC- $\delta$ or $-\epsilon$ were noted in either cytosolic or membrane fractions after $10 \mathrm{~min}$ of $1 \mathrm{nM}$ VEGF stimulation (data not shown). Although no significant changes were

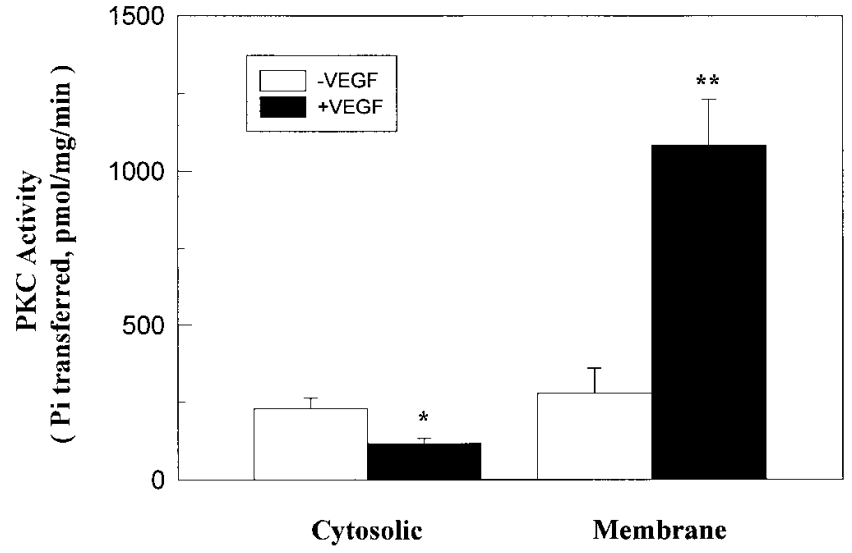

Figure 2. VEGF effect on PKC translocation. After stimulation with or without VEGF ( $0.5 \mathrm{nmol} /$ liter) for $10 \mathrm{~min}$, total PKC specific activities were measured in both cytosolic and membrane fraction from cultured BAEC. PKC activity was expressed as picomoles of Pi transferred per minute per milligram of protein. The results are shown as mean \pm SEM derived from three independent experiments, each performed in triplicate. ${ }^{*} P<0.05$, ${ }^{* *} P<0.001$. 


\section{A}
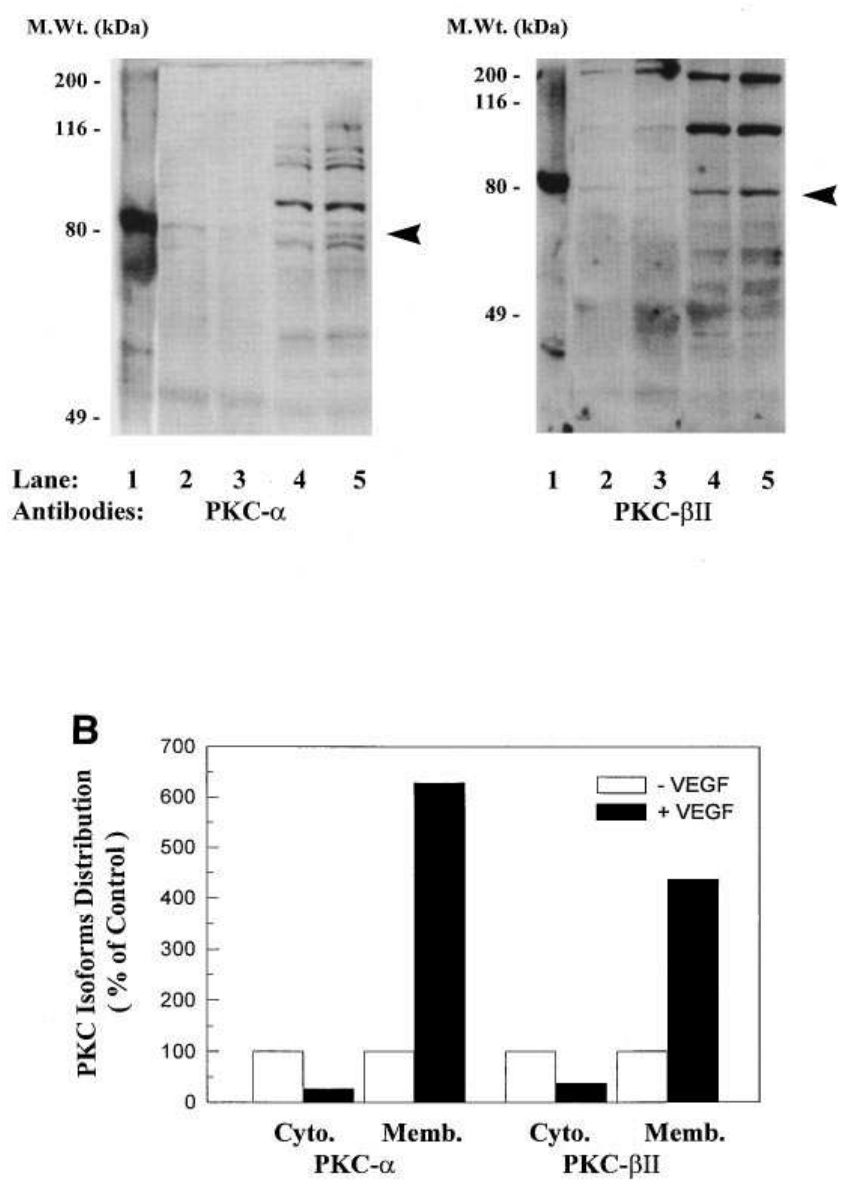

Figure 3. VEGF effect on the redistribution of PKC isoforms. (A) Immunoblotting analysis of PKC isoforms in cultured BAEC treated with or without VEGF as described above. Same amounts of protein partially purified from both cytosolic (lanes 2 and 3 ) and membrane (lanes 4 and 5) fractions were analyzed by $10 \%$ PAGE and probed with antibodies against peptides specific for PKC- $\alpha$ and $-\beta I I$. The arrow indicates each PKC isoform recognized by its specific antibody and comigration with its purified antigen. The figures represent autographs of the blots using the ECL system. Lane 1, purified PKC isoform ( $\alpha$ or $\beta \mathrm{II}$ ) peptide; lanes 2 and 4, absence of VEGF; lanes 3 and 5, presence of VEGF. (B) Graph depicting the relative amount of individual PKC isoforms. Data are plotted as percentage of control (absence of VEGF). Results are representative of three independent experiments.

demonstrated for PKC- $\beta_{1}$ and PKC- $\zeta$ isoforms, this finding may not be conclusive since only very small amounts of these two isoforms were detected.

Evaluation of VEGF-stimulated tyrosine phosphorylation of $P L C \gamma$. Since the enzymatic products of PLC $\gamma$ 's activation, DAG and inositol triphosphate $\left(\mathrm{IP}_{3}\right)$, activate PKC, we determined whether VEGF could activate PLC $\gamma$ in BAEC (26). Tyrosine phosphorylation level of PLC $\gamma$ was evaluated in cell lysates by immunoprecipitation with anti-PLC $\gamma$ antibodies and identified by immunoblotting using antiphosphotyrosine antibodies. VEGF $(1 \mathrm{nM})$ induced a several old increase in the tyrosine phosphorylation of a $145-\mathrm{kD}$ band, the reported molecular mass of PLC $\gamma$, and two other proteins (100 and $85 \mathrm{kD}$ ) known to be associated with PLCy (23) (Fig. 4). The addition
A M.Wt. (kDa)
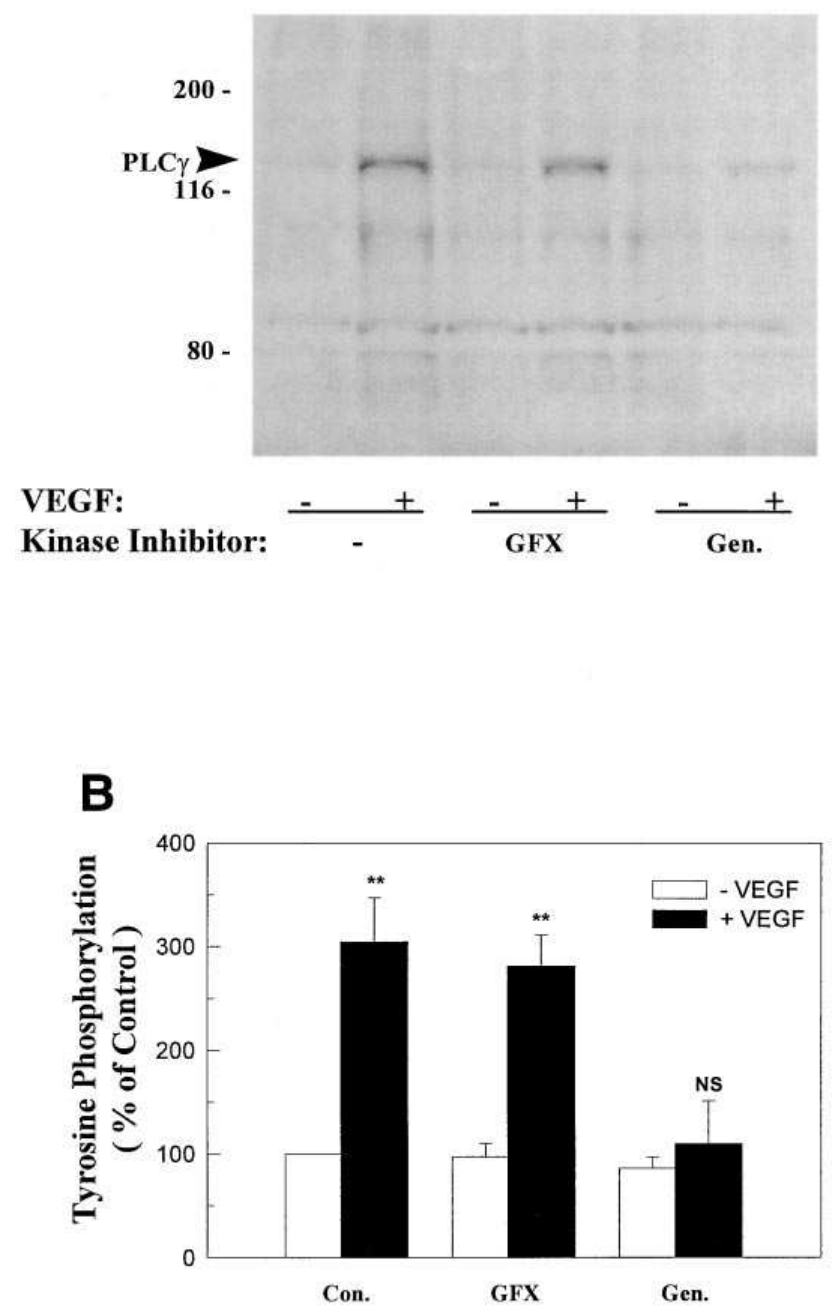

Figure 4. VEGF effect on tyrosine phosphorylation of PLC $\gamma .(A)$ Cultured BAEC were pretreated with a PKC-specific inhibitor, GFX $(5 \mu \mathrm{M})$, or a tyrosine kinase inhibitor, genistein $($ Gen., $40 \mu \mathrm{M})$, or $0.001 \%$ DMSO alone for $30 \mathrm{~min}$ and then stimulated with or without $0.5 \mathrm{nmol} /$ liter VEGF for $10 \mathrm{~min}$. PLC $\gamma$ in the cell lysates was immunoprecipitated with anti-PLC $\gamma$ antibody, separated by $4-12 \%$ SDSPAGE, and then probed with antiphosphotyrosine antibody as described in Methods. (B) Graph depicting the relative tyrosine phosphorylation of PLC $\gamma$. Data are plotted as percentage of control (mean $\pm \mathrm{SD}$ ) derived from three separate experiments with $P$ values relative to - VEGF control. $* * P<0.01$.

of genistein $(40 \mu \mathrm{m})$, a tyrosine kinase inhibitor (27), significantly reduced the VEGF-induced tyrosine phosphorylation of PLC $\gamma$. In contrast, GFX (5 $\mu \mathrm{m})$, a PKC inhibitor (28), did not significantly inhibit the tyrosine phosphorylation of PLCy.

Stimulation of DAG and inositol phosphate formation by $V E G F$. The products of PLC $\gamma$ 's enzymatic actions, DAG and inositol phosphates (26), were also determined. As shown in Fig. 5, VEGF ( $0.5 \mathrm{nmol} /$ liter $)$ induced a biphasic rise in the formation of DAG in BAEC prelabeled with $\left[{ }^{3} \mathrm{H}\right]$ arachidonic acid. The initial phase of labeled DAG formation reached a maximum within $1 \mathrm{~min}$. In the second phase, DAG formation was increased by six- to sevenfold with the second peak ob- 


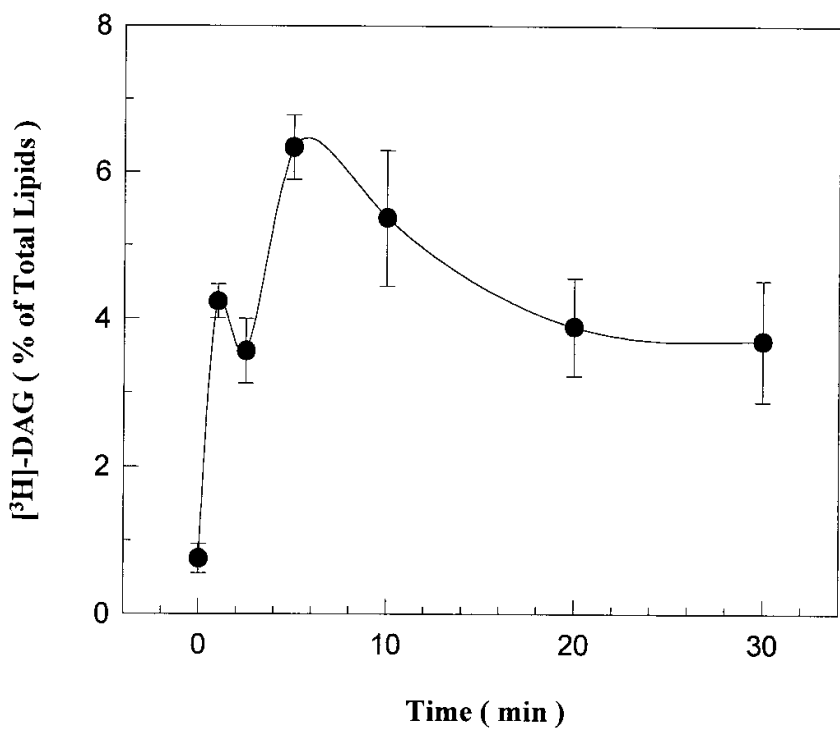

Figure 5. Time course of DAG formation induced by VEGF. BAEC were cultured to $80 \%$ confluence and prelabeled with $5 \mu \mathrm{Ci} / \mathrm{ml}$ $\left[{ }^{3} \mathrm{H}\right]$ arachidonic acid for $16 \mathrm{~h}$ before stimulation with $0.5 \mathrm{nmol} /$ liter VEGF. At the indicated times, DAG was extracted and measured as described in Methods. Results are mean \pm SEM derived from three separate experiments, each with triplicate determinations.

served at 5 min. Thereafter $\left[{ }^{3} \mathrm{H}\right]$ arachidonic-labeled DAG content decreased to approximately half-maximal levels within $15 \mathrm{~min}$ but continued to be elevated even after $30 \mathrm{~min}$.

The effect of VEGF on total $\left[{ }^{3} \mathrm{H}\right]$ inositol phosphates formation was also evaluated. Fig. 6 shows that increasing the concentration of VEGF from $5 \mathrm{pmol} /$ liter to $5 \mathrm{nmol} /$ liter caused a concentration-dependent increase in production of $\left[{ }^{3} \mathrm{H}\right]$ inositol phosphates within $10 \mathrm{~min}$. A concentration of 0.5 $\mathrm{nmol} /$ liter VEGF resulted in a three- to fourfold increase in

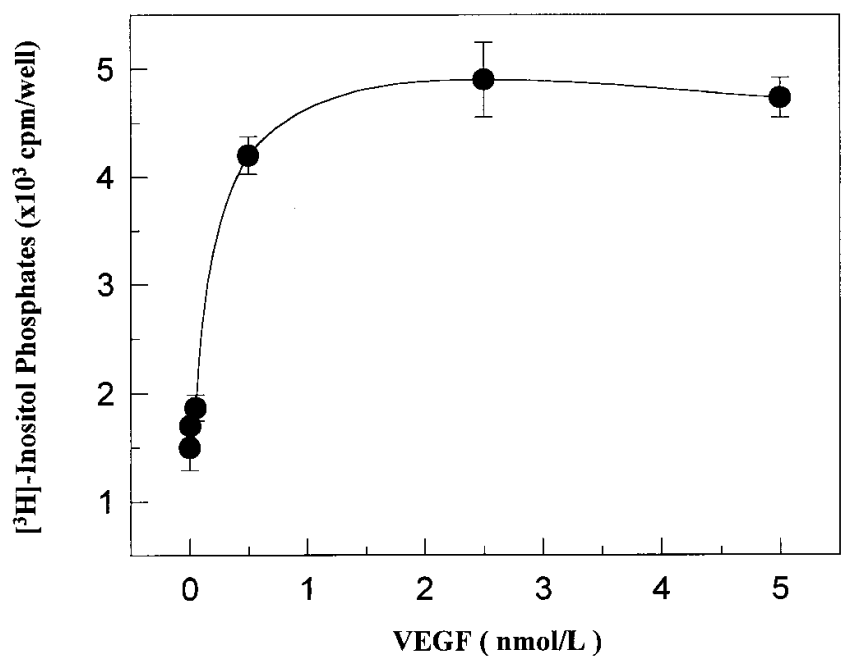

Figure 6. Dose dependence of VEGF-stimulated inositol phosphate production. Cultured BAEC were prelabeled with $\left[{ }^{3} \mathrm{H}\right]$ myo-inositol $(1 \mu \mathrm{Ci} / \mathrm{ml})$ for $16-20 \mathrm{~h}$ and then exposed to the indicated concentration of VEGF for $10 \mathrm{~min} .\left[{ }^{3} \mathrm{H}\right]$ Inositol phosphate was separated and quantified as described in Methods. Error bars indicate the range of values obtained for duplicate samples. These results are representative of three independent experiments.

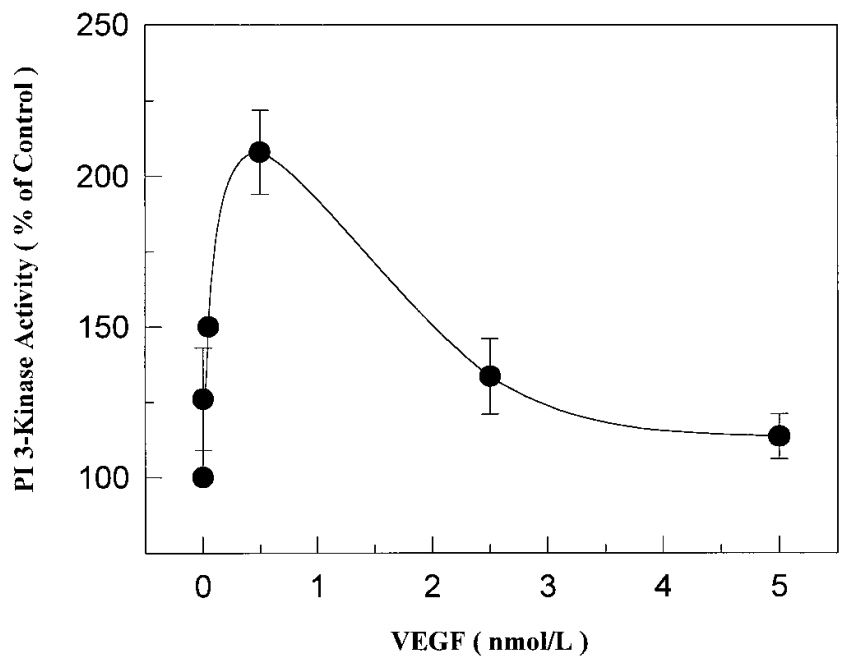

Figure 7. Dose response of VEGF-stimulated PI 3-kinase activation. Cultured BAEC were treated with an increasing dose of VEGF for $10 \mathrm{~min}$ and cell lysates were immunoprecipitated using antiphosphotyrosine antisera. PI 3-kinase activity in the washed immunoprecipitates was assayed as described. Error bars indicate the range of values obtained for duplicate samples. Results are representative of two separate experiments.

inositol phosphate production compared with basal levels. However, increasing VEGF concentration from $0.5 \mathrm{nmol} /$ liter to $5 \mathrm{nmol} /$ liter resulted in only a modest additional effect on the stimulation of inositol phosphate formation.

VEGF stimulates PI 3-kinase activity. Since PI 3-kinase has been shown to be associated with several different tyrosine kinase receptors (29), and VEGF has been reported to increase PI 3-kinase tyrosine phosphorylation $(12,13)$, we determined whether PI 3-kinase activity could also be activated by VEGF. Fig. 7 showed that VEGF induced increases in PI 3-kinase activity in a concentration-dependent manner. A minimal increase in PI 3-kinase activity was detectable when stimulated by VEGF at $5 \mathrm{pmol} /$ liter. Maximal stimulation of 1.7-2.1-fold was observed with $0.5 \mathrm{nmol} /$ liter of VEGF. Interestingly, a biphasic response was observed. VEGF became less effective at concentrations of $2.5 \mathrm{nmol} /$ liter or greater. The addition of wortmannin $(100 \mathrm{ng} / \mathrm{ml})$ inhibited PI-3 kinase activities in BAEC by $90 \%$.

Effects of PI-3 kinase, PKC, and tyrosine kinase inhibitors on VEGF-induced PKC activation and cell growth. We evaluated the role of VEGF-induced PLC $\gamma$ and PI 3-kinase activity on the activation of PKC in cultured BAEC. As shown in Fig. 8 $A$, VEGF-induced PKC activity was suppressed by the tyrosine kinase inhibitor genistein $(40 \mu \mathrm{M})$ and the PKC inhibitors GFX $(5 \mu \mathrm{M})$ and $\mathrm{H}-7(40 \mu \mathrm{M})$. Wortmannin, which inhibited PI 3-kinase $(30,31)$ in these studies by $90 \%$, did not inhibit VEGF-induced PKC activity even at a concentration of $100 \mathrm{nM}$.

Biologically, VEGF increased DNA content of BAEC in a concentration-dependent manner with significant increases observed initially at $0.01 \mathrm{nmol} /$ liter and maximally at 0.25 $\mathrm{nmol} /$ liter, consistent with our previous report $(5,32)$. Due to these findings, the effect of VEGF was studied using $0.5 \mathrm{nmol} /$ liter which consistently increased DNA content in BAEC by twofold after $3 \mathrm{~d}$ (Fig. $8 \mathrm{~B}$ ). The addition of PKC inhibitors 

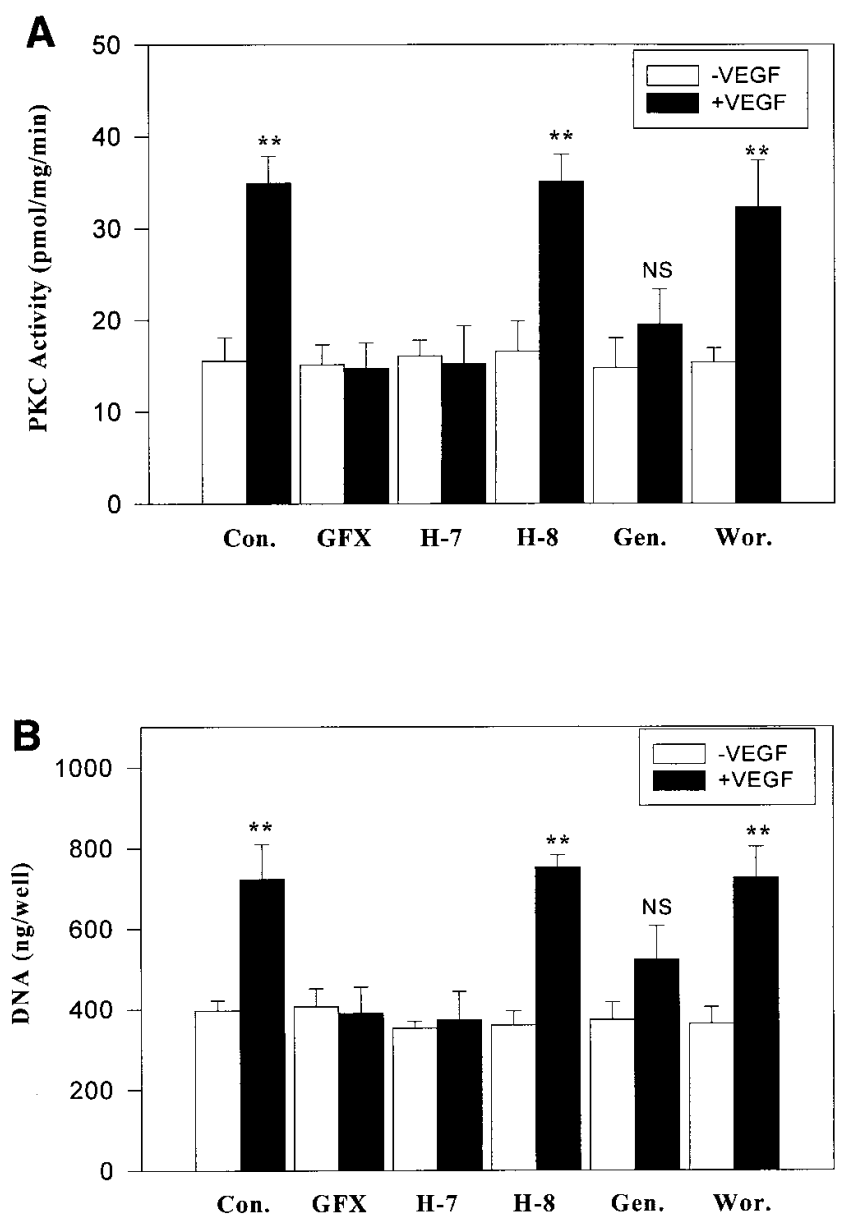

Figure 8. VEGF's mitogenic effect is dependent on PKC activity but independent of PI 3-kinase. ( $A$ ) Cultured BAEC were treated with or without $0.5 \mathrm{nmol} /$ liter VEGF after pretreatment with a variety of protein kinase inhibitors such as a PKC-specific inhibitor, GFX $(5 \mu \mathrm{M})$; a nonspecific protein kinase inhibitor, $\mathrm{H}-7(40 \mu \mathrm{M})$ and its inactive analogue, H-8 $(40 \mu \mathrm{M})$; a tyrosine kinase inhibitor, genistein (Gen., 40 $\mu \mathrm{M}$ ); a PI 3-kinase inhibitor, wortmannin (Wor., $0.1 \mu \mathrm{M}$ ), or $0.001 \%$ DMSO alone (Con.) for $30 \mathrm{~min}$. PKC activity was measured in situ as described in the legend to Fig. 1. (B) BAEC were seeded in 12-well plates at a density of 5,000/well. After $24 \mathrm{~h}, \mathrm{VEGF}$ and the indicated agents were added to the cultures. Media with wortmannin were changed every $24 \mathrm{~h}$. DNA content was measured after $3 \mathrm{~d}$. Results are expressed as mean \pm SEM derived from three separate experiments, each with triplicate determinations. ${ }^{* *} P<0.01 \mathrm{vs.} \mathrm{control}$ without VEGF stimulation.

GFX $(5 \mu \mathrm{M})$ or H-7 $(40 \mu \mathrm{M})$, as well as the tyrosine kinase inhibitor genistein $(40 \mu \mathrm{M})$, blocked VEGF-stimulated cell growth completely, in parallel with their inhibition of PKC activity. In contrast, H-8 (40 $\mu \mathrm{M})$, a control for $\mathrm{H}-7$, did not inhibit PKC activity or VEGF-induced BAEC proliferation. Although wortmannin at $100 \mathrm{nmol} /$ liter abolished VEGFinduced increases in PI 3-kinase activity (data not shown), it did not inhibit either VEGF-induced PKC activation or cell growth. In cells not stimulated by VEGF, the addition of GFX $(5 \mu \mathrm{M})$ did not reduce the basal level of DNA synthesis (data not shown). Therefore, GFX only inhibited VEGF-stimulated cell growth but did not affect basal growth rates of endothelial cells stimulated by serum.
Effect of PKC- $\alpha$ and $-\beta$ isoforms on VEGF's mitogenic effect. As described above, we found that VEGF-induced PKC mainly resulted in increasing $\mathrm{PKC}-\alpha$ and $-\beta \mathrm{II}$ isoforms in the membrane fraction. To evaluate further which isoform(s) of PKC activation are more specifically involved in VEGF-induced BAEC proliferation, we characterized the effect of an isoformselective inhibitor of PKC- $\beta$, LY333531 (15), and antisense PKC- $\alpha$ oligonucleotides. VEGF-induced BAEC proliferation was inhibited by the addition of PKC- $\beta$ (LY333531) inhibitor in a concentration-dependent manner (Fig. $9 A$ ). This inhibitory effect of LY333531 was significant at a concentration of 10 nmol/liter which we had reported previously to inhibit only PKC- $\beta$ isoform but not $\alpha$ isoform (15). Increasing the concentration of LY333531 to $50 \mathrm{nmol} /$ liter completely inhibited VEGF-stimulated cell growth, while only inhibiting VEGFinduced total PKC activity by $31 \%$ (Fig. 9 B).

The role of PKC- $\alpha$ isoform on VEGF-stimulated cell

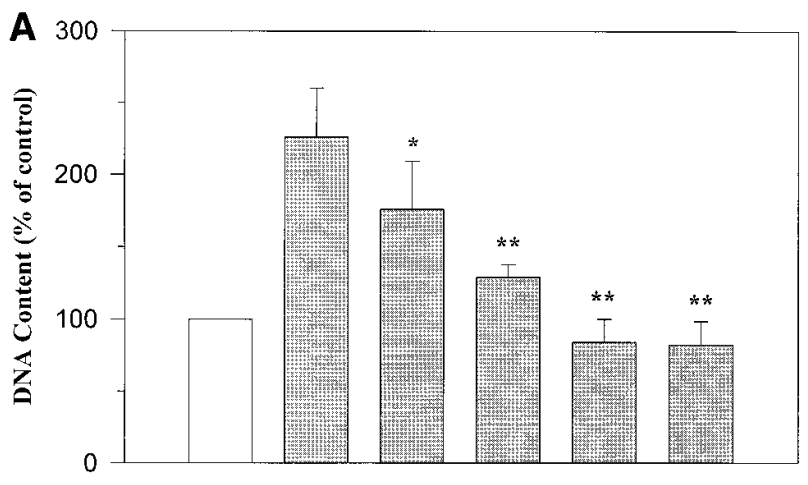

$\begin{array}{llllllr}\text { VEGF }(0.5 \mathrm{nmol} / \mathrm{L}) & - & + & + & + & + & + \\ \text { LV333531 }(\mathrm{nmol} / \mathrm{L}) & - & - & 10 & 25 & 50 & 100\end{array}$

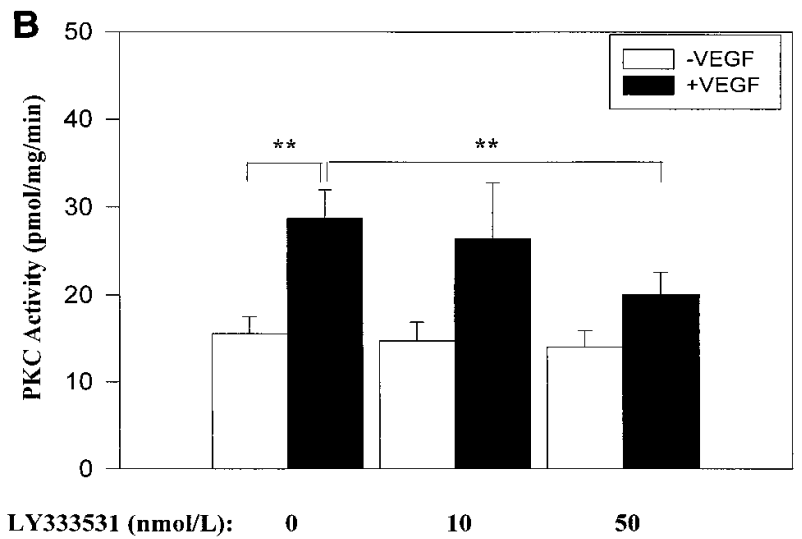

Figure 9. PKC- $\beta$ isoform-specific inhibition blocks VEGF-induced mitogenesis. $(A)$ The noted concentration of PKC- $\beta$-specific inhibitor LY333531 was added to the cultures of BAEC in DME containing $10 \%$ PDHS with or without $0.5 \mathrm{nmol} /$ liter of VEGF, and the media were changed every $24 \mathrm{~h}$. After $3 \mathrm{~d}$ of incubation, DNA content was measured. (B) Cultured BAEC were treated with or without 0.5 $\mathrm{nmol} /$ liter VEGF after pretreatment with LY333531 at the designated concentration for $30 \mathrm{~min}$. PKC activity was measured in situ as described in the legend to Fig. 1. Results are expressed as mean \pm SEM derived from three separate experiments, each with triplicate determinations. $* P<0.01, * * P<0.001$, treated with VEGF in absence of LY333531 versus presence of LY333531. 
A
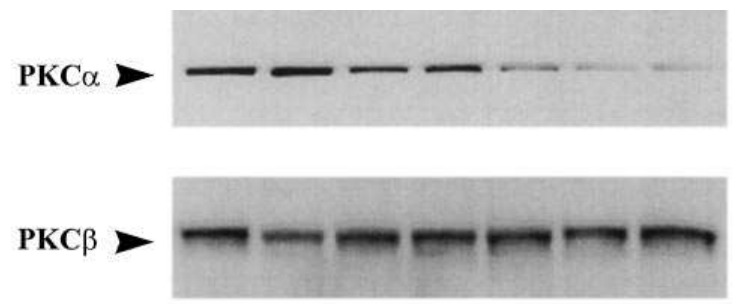

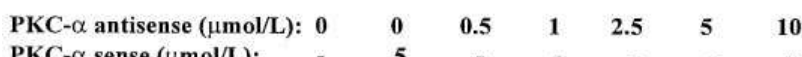

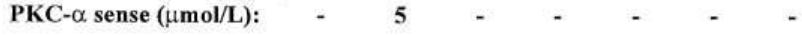

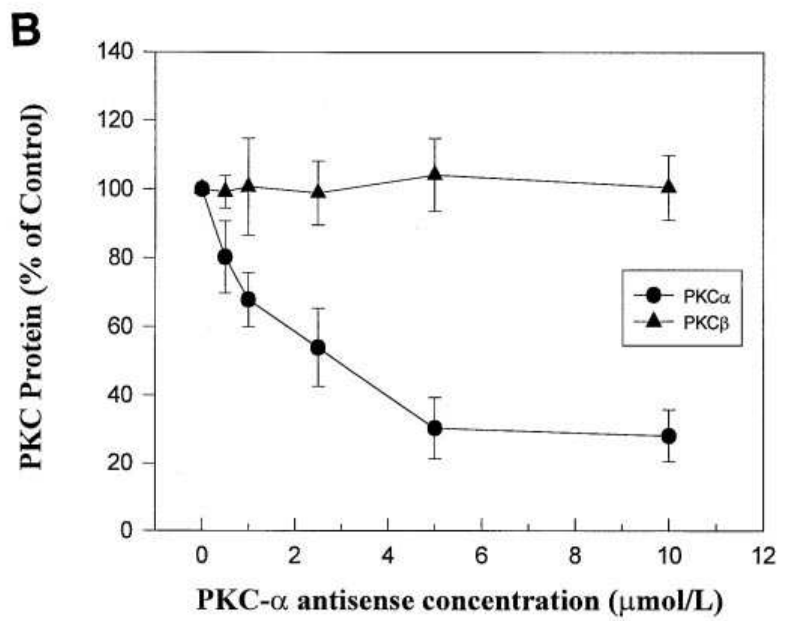

Figure 10. Antisense PKC- $\alpha$ oligonucleotide inhibition of PKC- $\alpha$ protein synthesis. ( $A$ ) BAEC were incubated in absence (control) or presence of the noted concentration of oligonucleotide (sense or antisense) for $3 \mathrm{~d}$. The cellular proteins were then extracted, and PKC- $\alpha$ and PKC- $\beta$ were determined by immunoblotting analysis (see Methods). PKC- $\alpha$ and PKC- $\beta$ are indicated by arrows on the left identified by a positive control (rat brain). (B) Levels of immunoreactive PKC- $\alpha$ and PKC- $\beta$ protein from the above gels and others from separate experiments were quantified with a PhosphorImager and are expressed as a percentage of control. Values are mean $\pm \mathrm{SD}, n=3$ (these separate experiments).

growth was also characterized. Fig. 10 shows that $\mathrm{PKC}-\alpha$ protein levels were specifically inhibited by $>75 \%$ with the addition of antisense PKC- $\alpha$ oligonucleotides in cultured BAEC. However, sense PKC- $\alpha$ oligonucleotides did not have any significant effect on PKC- $\alpha$ levels. This inhibition by antisense $\mathrm{PKC}-\alpha$ oligonucleotide was dose-dependent and isotype-specific since PKC- $\beta$ protein levels were unaffected although the protein levels of PKC- $\alpha$ isoforms were reduced by $>75 \%$. The addition of antisense PKC- $\alpha$ oligonucleotides did not inhibit, but rather enhanced, both basal and VEGF-stimulated mitogenic effects significantly in BAEC (Fig. 11).

\section{Discussion}

VEGF has been reported to induce multiple biological actions in endothelial cell such as stimulating cellular proliferation and increasing vascular permeability (1-3). The initial step for VEGF to mediate its cellular actions is binding to specific, high-affinity receptors on endothelial cells. Two of these re-

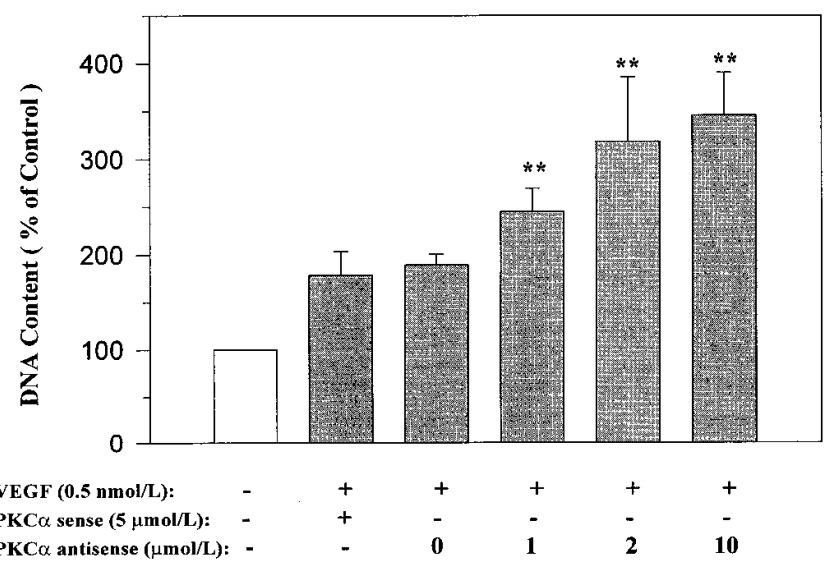

Figure 11. Effect of PKC- $\alpha$ antisense on VEGF-induced cell growth. BAEC were seeded in 12-well plates at a density of 5,000/well. After $24 \mathrm{~h}$, the oligonucleotides were added to the medium in presence of 0.5 nM VEGF. Media with oligonucleotides and VEGF were changed every $24 \mathrm{~h}$. DNA content was measured after $3 \mathrm{~d}$. Results are expressed as mean \pm SEM derived from three separate experiments, each with triplicate determinations. ${ }^{* *} P<0.001$ vs. control without antisense.

ceptors, Flk-1/KDR and Flt-1, have been identified and contain tyrosine kinase activities $(10,11)$, and are phosphorylated at tyrosine residues. Both micro- and macrovascular endothelial cells contain these receptors although we have reported that endothelial cells from the retinal capillaries may express more receptors than aortic endothelial cells (32).

Several recent reports have shown that Flk-1/KDR receptors, when activated, will associate with PLC $\gamma$, GTPase-activating protein, Nck, and PI 3-kinase $(12,13)$. These interactions are probably mediated through $\mathrm{SH} 2$ domains, resulting in the tyrosine phosphorylation of these potential substrates. Since tyrosine phosphorylation of PLCy and PI 3-kinase are associated with their activation, it is surprising that Waltenberger et al. (13) were not able to show an increase in PI 3-kinase activity after VEGF stimulation. Our results demonstrate that VEGF activation of PI 3-kinase involves tyrosine phosphorylation since PI 3-kinase activities were measured using antiphosphotyrosine antibody immunoprecipitates. Interestingly, the dose-response curve showed a biphasic pattern with the first phase demonstrating maximum stimulation at $1 \mathrm{nM}$ which coincided with VEGF's mitogenic effect. However, the lack of effect on PI 3-kinase activity after $2.5 \mathrm{nM}$ was unlike that of VEGF's growth effect which is sustained at $2 \mathrm{nM}$ (32) or greater levels.

In addition to stimulating PI 3-kinase activity, our findings have provided the first demonstration that VEGF can activate PLC $\gamma$ which is consistent with previous reports that VEGF can increase PLC $\gamma$ tyrosine phosphorylation (13). The time course of PLC $\gamma$ activation was very rapid and similar to the activation of PI 3-kinase. In contrast, the dose-response curve for the activation of PLC $\gamma$ was quite different from that of PI 3-kinase since VEGF continued to be effective even at $5 \mathrm{nM}$, a concentration where VEGF failed to have a stimulating effect on PI 3-kinase. This latter finding suggested that VEGF was activating PI 3-kinase and PLC $\gamma$ via different pathways.

The activation of PKC by VEGF appears to be the result of PLC $\gamma$ activation and the production of DAG and $\mathrm{IP}_{3}$ which 
can directly or indirectly activate PKC by the mobilization of $\mathrm{Ca}^{2+}(25,34)$. This is the first direct demonstration of the activation of PKC and its isoform by VEGF. This finding has been confirmed by both in situ and translocation assays. The time course of VEGF-induced PKC activation was rapid but appeared to follow the increases of $\mathrm{IP}_{3}$ and DAG. In addition, the dose-response curve was very similar to PLC $\gamma$ activation without diminution of VEGF's effect at concentrations of 5 $\mathrm{nM}$ or greater, thus indicating that VEGF was sequentially activating PLC $\gamma$ and then PKC.

Vascular endothelial cells contain multiple isoforms of PKC (15). The present studies together with our previous studies have shown that vascular endothelial cells contain various amount of PKC isoforms $\alpha, \beta_{1}, \beta_{2}, \delta, \epsilon$, and $\zeta$ but not $\gamma(15,35)$. It is also possible that other $\mathrm{PKC}$ isoforms which were not studied could be present. However, it is interesting to note that only $\alpha$ and $\beta_{2}$ isoforms were found to be consistently translocated, whereas PKC- $\delta$ and $-\epsilon$ were not. The explanation for the difference among the various PKC isoforms is not clear but could be multiple, ranging from differences in time of activation and degradation to different efficiencies of the various antibodies. It is interesting to speculate that the predominant activation of $\alpha$ and $\beta$ isoforms could be the result of VEGF inducing increases in both DAG levels and $\left[\mathrm{Ca}^{2+}\right]$ flux which can in concert stimulate PKC isoforms $\alpha$ and $\beta$ to translocate since both of these isoforms contain DAG and $\mathrm{Ca}^{2+}$ binding sites (24). In contrast, PKC isoforms $\epsilon$ and $\delta$, which lack $\mathrm{Ca}^{2+}$ binding sites, are only responsive to DAG and did not translocate adequately for our antibodies to detect (25).

The findings thus far have clearly demonstrated that VEGF can induce the activation of at least two signaling pathways, possibly in a parallel manner. Both the activation of PI 3-kinase and PLC $\gamma$-PKC pathways are associated with mitogenic effects of growth factors $(26,29)$. However, our studies suggest that VEGF's growth promoting effects can be partially mediated by the activation of PLC $\gamma$ and the PKC pathway. Supportive evidence for $\mathrm{PKC}$ is derived from studies using non-isoform-specific PKC inhibitors GFX and H7. The inhibitory effects of GFX and $\mathrm{H} 7$ on the mitogenic action of VEGF were probably not due to nonspecific or toxic effects of these compounds since endothelial cells continue to grow slowly when stimulated by serum in the presence of GFX and H7. When PKC inhibitor GFX was used, PKC activity was inhibited but the activation of PLC $\gamma$ was not affected since PLC $\gamma$ activation most likely preceded PKC activation. These findings suggested that PKC activation played a role in the mitogenic action of VEGF. Further, inhibitors of PKC have been reported by others to inhibit angiogenesis induced by VEGF although PKC activity was not measured (33).

The strongest support for the postulate that PKC activation is involved in the mitogenic effects of VEGF is derived from the use of PKC isoform selective inhibitor LY333531 which we have recently reported to inhibit PKC isoform $\beta$ at concentrations 50- and 1,000-fold less than other PKC isoforms and various tyrosine or serine-threonine kinases, respectively (15). The present study showed that LY333531 inhibited VEGF-induced endothelial cell proliferation even at concentrations below 25 $\mathrm{nM}$ which clearly indicated that PKC activation was necessary for VEGF's mitogenic effect. In addition, these results suggested that VEGF's growth effect was mediated predominately by PKC- $\beta$ isoform. This possibility was supported by two sets of results. First, the concentration response curve for
LY333531's inhibition of VEGF-induced growth in endothelial cells corresponded very closely to its inhibitory profile for PKC- $\beta$ isoform, as we have reported previously (15). Indeed, dose response for inhibition by LY333531 on total VEGFinduced PKC activity was much less potent than its effect on cell growth (Fig. 3). This difference was probably due to the fact that VEGF will stimulate the activation of multiple PKC isoforms whereas the growth effect was predominately mediated by the PKC- $\beta$ isoform. Second, the results of experiments using antisense to $\mathrm{PKC}-\alpha$ showed that it did not inhibit VEGF's growth effect despite decreasing PKC- $\alpha$ protein levels by $75-80 \%$. The decrease in PKC- $\alpha$ protein levels actually enhanced both basal and VEGF stimulated endothelial cell growth, suggesting that PKC- $\alpha$ has inhibitory effects on endothelial cell growth. These data again suggest that activation of PKC- $\beta$ isoform was important for VEGF-mediated growth.

In contrast, wortmannin at concentrations that inhibited PI 3-kinase did not decrease the VEGF-mediated increase of PKC activity, thus suggesting that the PI 3-kinase pathway was not involved in VEGF's activation of PKC. Although wortmannin did not inhibit VEGF's effect on DNA synthesis, it was not clear from this study whether the PI 3-kinase pathway could also play a role in VEGF's mitogenic action since the effects of wortmannin are relatively short lived. It is interesting to speculate that the activation of PI 3-kinase may affect other important cellular actions of VEGF such as the regulation of vascular permeability. The finding that genistein, a nonspecific tyrosine-kinase inhibitor, blocked VEGF-induced PLC $\gamma$ and PKC activity and subsequent cell growth was not surprising since receptors for VEGF are known to be tyrosine kinases. In addition, genistein could be inhibiting many other tyrosine kinases to decrease cell growth.

In summary, these results have demonstrated that VEGF can activate both PI 3-kinase and the PLC $y-P K C$ signal transduction pathways. In addition, the activation of $\mathrm{PKC}$ is not regulated by PI 3-kinase, whereas the PKC- $\beta$ isoform is predominately mediating VEGF's mitogenic actions. Further studies will be needed to clarify the molecular mechanism by which specific PKC isoforms regulate DNA synthesis in endothelial cells. These findings also suggest that isoform-specific PKC inhibitors might prove useful as antiangiogenic agents in those pathological disorders such as diabetic proliferative retinopathy where VEGF levels have been reported to be elevated (8).

\section{Acknowledgments}

The authors wish to thank Ms. Joan C. Taylor for her excellent assistance in preparing this manuscript. In addition, the authors wish to thank Dr. Napoleone Ferrara for providing the VEGF and valuable discussion on the preparation of this manuscript. The authors would also like to express their appreciation to Dr. Lawrence Ballas for providing the purified PKC- $\alpha,-\beta_{1},-\beta_{2},-\gamma,-\epsilon$, and $-\delta$ derived from baccloviral system.

This study was supported by National Institutes of Health grants EY05110 (G.L. King), EY10827 (L.P. Aiello), and DK36433 which supported the Diabetes Endocrinology Research Center.

\section{References}

1. Leung, D.W., G. Cachianes, W.J. Kuang, D.V. Goeddel, and N. Ferrara. 1989. Vascular endothelial growth factor is a secreted angiogenic mitogen. Science (Wash. DC). 246:1306-1309. 
2. Ferrara, N., K.A. Houck, L.B. Jakeman, and D.W. Leung. 1992. Molecular and biological properties of the vascular endothelial growth factor family of proteins. Endocr. Rev. 13:18-32.

3. Berse, B., L.F. Brown, L. Van de Water, H.F. Dvorak, and D.R. Senger. 1992. Vascular permeability factor (vascular endothelial growth factor) gene is expressed differentially in normal tissues, macrophages, and tumors. Mol. Biol. Cell. 3:211-220.

4. Shweiki, D., A. Itin, D. Soffer, and E. Keshet. 1992. Vascular endothelial growth factor induced by hypoxia may mediate hypoxia-initiated angiogenesis. Nature (Lond.). 359:843-845.

5. Aiello, L.P., J.M. Northrup, B.A. Keyt, H. Takagi, and M.A. Iwamoto. 1995. Hypoxic regulation of vascular endothelial growth factor in retinal cells. Arch. Ophthalmol. 113:1538-1544.

6. Adamis, A.P., D.T. Shima, K.T. Yeo, T.K. Yeo, L.F. Brown, B. Berse, P.A. D'Amore, and J. Folkman. 1993. Synthesis and secretion of vascular permeability factor/vascular endothelial growth factor by human retinal pigment epithelial cells. Biochem. Biophys. Res. Commun. 193:631-638.

7. Plate, K.H., G. Breier, H.A. Weich, and W. Risau. 1992. Vascular endothelial growth factor is a potential tumour angiogenesis factor in human gliomas in vivo. Nature (Lond.). 359:845-848.

8. Aiello, L.P., R.L. Avery, P.G. Arrigg, B.A. Keyt, H.D. Jampel, S.T. Shah, H. Thieme, M.A. Iwamoto, J.E. Park, H.V. Nguyen, et al. 1994. Vascular endothelial growth factor in ocular fluid of patients with diabetic retinopathy and other retinal disorders. N. Engl. J. Med. 331:1480-1487.

9. Miller, J.W., A.P. Adamis, D.T. Shima, P.A. D'Amore, R.S. Moulton, M.S. O'Reilly, H.F. Dvorak, L.F. Brown, B. Berse, et al. 1994. Vascular endothelial growth factor/vascular permeability factor is temporally and spatially correlated with ocular angiogenesis in a primate model. Am. J. Pathol. 145:574584.

10. De Vries, C., J.A. Escobedo, H. Ueno, K. Houck, N. Ferrara, and L.T. Williams. 1992. The fms-like tyrosine kinase, a receptor for vascular endothelial growth factor. Science (Wash. DC). 255:989-991.

11. Millauer, B., S. Wizigmann-Voos, H. Schnurch, R. Martinez, N.P. Moller, W. Risau, and A. Ullrich. 1993. High affinity VEGF binding and developmental expression suggest Flk-1 as a major regulator of vasculogenesis and angiogenesis. Cell. 72:835-846.

12. Guo, D., Q. Jia, H.Y. Song, R.S. Warren, and D.B. Donner. 1995. Vascular endothelial cell growth factor promotes tyrosine phosphorylation of mediators of signal transduction that contain $\mathrm{SH} 2$ domains. Association with endothelial cell proliferation. J. Biol. Chem. 270:6729-6733.

13. Waltenberger, J., L. Claessonwelsh, A. Siegbahn, M. Shibuya, and C.H. Heldin. 1994. Different signal transduction properties of KDR and FLT1, two receptors for vascular endothelial growth factor. J. Biol. Chem. 269:2698826995.

14. Toker, A., M. Meyer, K.K. Reddy, J.R. Falck, R. Aneja, S. Aneja, A. Parra, D.J. Burns, L.M. Ballas, and L.C. Cantley. 1994. Activation of protein kinase $\mathrm{C}$ family members by the novel polyphosphoinositides ptd1ns-3, 4-P.2 and ptdns-3,4,5-P3. J. Biol. Chem. 269:32358-32367.

15. Ishii, H., M.R Jirousek, D. Koya, C. Takagi, P. Xia, A Clermont, S.-E. Bursell, T.S. Kern, L.M. Ballas, W.F. Heath, et al. 1996. Amelioration of vascular dysfunctions in diabetic rats by an oral PKC $\beta$ inhibitor. Science (Wash. DC). 272:728-731.

16. Xia, P., T. Inoguchi, T.S. Kern, R.L. Engerman, P.J. Oates, and G.L. King. 1994. Characterization of the mechanism for the chronic activation of diacylglycerol-protein kinase $\mathrm{C}$ pathway in diabetes and hypergalactosemia. Diabetes. 43:1122-1129.

17. Heasley, L.E., and G.L. Johnson. 1989. Regulation of protein kinase C by nerve growth factor, epidermal growth factor and phorbol esters in PCI2 pheochromocytoma cells. J. Biol. Chem. 264:8646-8652.

18. Xia, P., R.M. Kramer, and G.L. King. 1995. Identification of the mechanism for the inhibition of $\mathrm{Na}, \mathrm{K}$-adenosine triphosphatase by hyperglycemia in volving activation of protein kinase $\mathrm{C}$ and cytosolic phospholipase $\mathrm{A}_{2}$. J. Clin. Invest. 96:733-740.

19. Bradford, M.M. 1976. A rapid and sensitive method for the quantitation of microgram quantities of protein utilizing the principle of protein-dye binding. Anal. Biochem. 72:248-254.

20. Inoguchi, T., P. Xia, M. Kunisaki, S. Higashi, E.P. Feener, and G.L. King. 1994. Insulin's effect on protein kinase C and diacylglycerol induced by diabetes and glucose in vascular tissues. Am. J. Physiol. 267:E369-E379.

21. Aris, J.P., P.V. Basta, W.D. Holmes, L.M. Ballas, C. Moomaw, N.B Rankl, G. Blobel, C.R. Loomis, and D.J. Burns. 1993. Molecular and biochemical characterization of a recombinant human PKC $\delta$ family member. Biochim. Biophys. Acta. 1174:171-181.

22. Bligh, E.G., and W.J. Dyer. 1959. A rapid method of total lipid extraction and purification. Can. J. Biochem. Physiol. 37:911-917.

23. Downes, C.P., P.T. Hawkins, and R.F. Irvine. 1986. Inositol 1,3,4,5-tetrakisophosphate and not phosphatidylinositol 3,4-bisphosphate is the probable precursor of inositol 1,2,4-triphosphate in agonist-stimulated parotid gland. Biochem. J. 238:501-506.

24. Folli, F., M.J.A. Saad, J.M. Backer, and C.R. Kahn. 1992. Insulin stimulation of phosphatidylinositol 3-kinase activity and association with IRS-1 in liver and muscle of the intact rat. J. Biol. Chem. 267:22171-22177.

25. Nishizuka, Y. 1992. Intracellular signaling by hydrolysis of phospholipids and activation of protein kinase C. Science (Wash. DC). 258:607-614.

26. Park, D., and S.G. Rhee. 1992. Phosphorylation of Nck in response to a variety of receptors, phorbol myristate acetate and cyclic AMP. Mol. Cell. Biol. 12:5816-5823.

27. Akiyama, T., J. Ishida, S. Nakagawa, H. Ogawara, S. Watanabe, N. Itoh, M. Shibuya, and Y. Fukami. 1987. Genistein, a specific inhibitor of tyrosinespecific protein kinases. J. Biol. Chem. 262:5592-5595.

28. Toullec, D., P. Pianetti, H. Coste, P. Bellevergue, T. Grand-Perret, M. Jakanes, V. Baudet, P. Boissin, E. Boursier, F. Loriolle, et al. 1991. The bisindalylmaleimide GF109203X is a potent and selective inhibitor of protein kinase C. J. Biol. Chem. 266:15771-15781.

29. Cantley, L.C., K.R. Auger, C. Carpenter, B. Duckworth, A. Graziani, R. Kapeller, and S. Soltoff. 1991. Oncogenes and signal transduction. Cell. 64:281302 .

30. Okada, T., L. Sakuma, Y. Fukui, O. Hazeki, and M. Ui. 1994. Blockage of chemotactic peptide induced stimulation if neutrophils by wortmannin as a result of selective inhibition of phosphatidylinositol 3-kinase. J. Biol. Chem. 269:3563-3567.

31. Cheatham, B., C.J. Vlahos, L. Cheatham, L. Wang, J. Blenis, and C.R. Kahn. 1994. Phosphatidylinositol 3-kinase activation is required for insulin stimulation of pp70 S6 kinase, DNA synthesis, and glucose transporter translocation. Mol. Cell. Biol. 14:4902-4911.

32. Thieme, H., L.P. Aiello, H. Takagi, N. Ferrara, and G.L. King. 1995. Comparative analysis of vascular endothelial growth factor (VEGF) receptors on retinal and aortic microvascular endothelial cells. Diabetes. 44:98-103.

33. Friedlander, M., P.C. Brooks, R.W. Scaffer, C.M. Kincaid, J.A. Varner, and D.A. Cheresh. 1995. Definition of two angiogenic pathways by distinct $\gamma$ integrins. Science (Wash. DC). 270:1500-1502.

34. Rhee, S.G., P.-G. Suh, S.-H. Ryu, and S.Y. Lee. 1989. Studies of inositol phospholipid-specific phospholipase C. Science (Wash. DC). 244:546-550.

35. Shiba, T., T. Inoguchi, J.R. Sportsman, W.F. Heath, S.-E. Bursell, and G.L. King. 1993. Correlation of diacylglycerol level and protein kinase C activity in rat retina to retinal circulation. Am. J. Physiol. 265:E783-E793. 